\title{
PERBEDAAN GENDER PADA RESPON FUNGSI EMOSIONAL TERHADAP TOKOH ANTAGONIS: SEBUAH STUDI PADA MAHASISWA SASTRA INGGRIS
}

\author{
Oleh : Ruisah, SS, M.I.Kom.
}

Dosen Sastra Inggris Universitas Universitas Pamulang

reneyowae@yahoo.com

\begin{abstract}
ABSTRAK
Penelitian ini bertujuan untuk mengetahui dan mengungkap bagaimana perbedaan gender memberikan respon fungsi emosional yang berkecenderungan memihak jenis kelamin pada tokoh fiksi dan tidak lepas dari isu gender. Ketimpangan peran sosial berdasarkan gender (gender inequality) dianggap sebagai divine creation, segalanya bersumber dari Tuhan. Berbeda dengan persepsi para feminis yang menganggap ketimpangan itu semata-mata sebagai konstruksi masyarakat (social construction). Pandangan para ahli psikologi mengenai gender adalah menyangkut karakteristik kepribadian yang dimiliki oleh individu, yaitu maskulin, feminin, androgini dan tak terbedakan. Masing-masing karakteristik kepribadian gender tersebut memiliki karakteristik tersendiri, yang mempengaruhi perilaku seseorang, dalam penelitian ini difokuskan pada respon mahasiswa setelah membaca karya fiksi dengan membatasi pada tokoh antagonis.

Dalam Women Studies Ensiklopedia dijelaskan bahwa gender adalah suatu konsep kultural, berupaya membuat perbedaan (distinction) dalam hal peran, perilaku, mentalitas, dan karakteristik emosional antara laki-laki dan perempuan yang berkembang dalam masyarakat, disebutkan bahwa emosi timbul setelah terjadinya reaksi psikologis. Emosi adalah hasil persepsi seseorang terhadap perubahan-perubahan yang terjadi pada tubuh sebagai respon terhadap berbagai rangsangan yang datang dari luar. Respon-respon tubuh ini kemudian di persepsikan dalam bentuk tulisan. Data dalam penelitian ini ialah data tertulis, berupa hasil respon tulisan dari mahasiswa program studi sastra Inggris.
\end{abstract}

Kata Kunci: Perbedaan Gender, Respon, Fungsi Emosional 


\section{PENDAHULUAN}

\section{A. Latar Belakang Masalah}

Penelitian ini bermula dari adanya perbedaan respon antara mahasiswa dan mahasiswi pasca membaca karya-karya prosa sebagai tindakan lanjut dalam kegiatan perkuliahan dan diskusi di dalam kelas. Perbedaan tersebut kemudian mengerucut pada konsep yang berbasis gender dan perbedaannya. Ada kecenderungan memihak atau keberpihakan peserta diskusi terhadap karakter fiksi pada karya sastra yang dibaca sesuai dengan jenis kelamin mereka. Perbedaan ini kemudian menjadi bahan kajian terkait teori Gender Differences secara fungsi emosional pada semua peserta diskusi.

\section{B. Latar Belakang Masalah}

Berdasarkan latar belakang tersebut diatas, maka permasalahan yang dapat di identifikasikan dalam penulisan ini adalah:

1. Perbedaan respon antara mahasiswa dan mahasiswi pasca membaca karya-karya prosa.

2. Perbedaan respon antara mahasiswa dan mahasiswi pasca membaca karya-karya prosa berdasarkan gender.

3. Ada kecenderungan memihak atau keberpihakan peserta diskusi terhadap karakter fiksi pada karya sastra yang dibaca sesuai dengan jenis kelamin mereka.

\section{Perumusan Masalah}

Berdasarkan identifikasi masalah di atas, penulis akan merumuskan masalah sebagai berikut :

1. Apakah ada perbedaan respon antara mahasiswa dan mahasiswi pasca membaca karyakarya prosa?

2. Bagaimana perbedaan respon antara mahasiswa dan mahasiswi pasca membaca karyakarya prosa berdasarkan gender?

3. Apakah ada kecenderungan memihak atau keberpihakan peserta diskusi terhadap karakter fiksi pada karya sastra yang dibaca sesuai dengan jenis kelamin mereka? 


\section{PEMBAHASAN}

\section{A. Perbedaan Gender}

Dalam Women Studies Ensiklopedia dijelaskan bahwa Gender adalah suatu konsep kultural, berupaya membuat perbedaan (distinction) dalam hal peran, perilaku, mentalitas, dan karakteristik emosional antara laki-laki dan perempuan yang berkembang dalam masyarakat. Gender didefinisikan sebagai suatu gambaran sifat, sikap dan perilaku laki-laki dan perempuan.

Perbedaan gender pada sosial dan fungsi emosional cenderung lebih besar daripada perbedaan gender pada performa kognitif. (Bjorklund \& Kipp, 199; Eagly \& Wood, 199; Keenan \& Shaw, 1997). Kebanyakan penelitian menyatakan bahwa wanita lebih mungkin daripada laki-laki untuk memelihara, menolong, terbuka, dipercaya, kooperatif, dan dapat menyembunyikan emosi mereka. Sedangkan laki-laki lebih mungkin untuk menjadi kompetitif, dominan, dan tegas (Eagly \& others, 2004). Perempuan cenderung saling menyukai daripada laki-laki lakukan (Rudman \& Goodwin, 2004), tetapiu laki-laki lebih mungkin untuk cemas, depresi, dan mempunyai self-esteem yang rendah.

\section{B. Pengertian Respon}

Respon adalah setiap tingkah laku pada hakekatnya merupakan tanggapan atau balasan terhadap rangsangan atau stimulus (Sarlito, 1995). Menurut Gulo (1996), respon adalah suatu reaksi atau jawaban yang bergantung pada stimulus atau merupakan hasil stimulus tersebut. Individu manusia berperan serta sebagai pengendali antara stimulus dan respon sehingga yang menentukan bentuk respon individu terhadap stimulus adalah stimulus dan faktor individu itu sendiri (Azwar, 1988).

Susanto (1988: 73) mengatakan respon merupakan reaksi, artinya penerimaan atau penolakan, serta sikap acuh tak acuh terhadap apa yang disampaikan oleh komunikator dalam pesannya. Respon dapat dibedakan menjadi opini (pendapat) dan sikap, dimana pendapat atau opini adalah jawaban terbuka (overt response) terhadap suatu persoalan yang dinyatakan dengan kata-kata yang diucapkan atau tertulis. Sedangkan sikap merupakan reaksi yang tertutup (convert response) yang bersifat emosional dan pribadi, merupakan 
tendensi untuk memberikan reaksi yang sangat positif atau negatif terhadap orang-orang, obyek, atau situasi tertentu.

\section{Pengertian Emosi}

Emosi berasal dari bahasa Latin, yaitu emovere, yang berarti bergerak menjauh. Arti kata ini menyiratkan bahwa kecenderungan bertindak merupakan hal mutlak dalam emosi. Daniel Goleman (2002) mengatakan bahwa emosi merujuk pada suatu perasaan dan pikiran yang khas, suatu keadaan biologis dan psikologis dan serangkaian kecenderungan untuk bertindak.

Thompson (1994) mendefinisikan regulasi emosi sebagai kemampuan individu untuk memonitor, mengevaluasi dan memodifikasi reaksi emosional untuk mencapai tujuan. Regulasi dipandang secara positif, individu yang melakukan regulasi emosi akan lebih mampu melakukan pengontrolan emosi. Individu yang mampu mengekspresikan emosi dapat mengubah lingkungan sosial menjadi lebih baik. Emosi adalah proses yang melibatkan banyak komponen yang bekerja terus menerus sepanjang waktu, regulasi emosi melibatkan perubahan dalam dinamika emosi, atau waktu munculnya, besarnya lamanya dan mengimbangi respon perilaku, pengalaman atau fisiologis. Regulasi emosi dapat mengurangi, memperkuat atau memelihara emosi tergantung pada tujuan individu. Berdasarkan pengertian di atas maka dapat disimpulkan bahwa regulasi emosi adalah kemampuan untuk tetap tenang dibawah tekanan, meliputi semua kesadaran dan ketidaksadaran strategi yang digunakan untuk menaikkan, memelihara, mengontrol dan menurunkan emosi sehingga berpengaruh pada perasaan, perilaku, dan respon fisiologis. Menurut Garnesfski strategi regulasi emosi yang baik adalah acceptance, refocus on planning, positive refocusing, positive reappraisal, putting into perspective, karena strategi regulasi emosi tersebut menunukkan tingkat optimis dan self esteem yang positive serta tingkat anxiety yang rendah. Sedangkan strategi emosi yang buruk menurut Garnesfski adalah self-blame, blaming others, rumination or, focus on thought, catastrophobizing karena strategi-strategi regulasi emosi tersebut menunjukkan atau diasosiasikan dengan tingkat depresi dan stress yang tinggi. Penelitian dilakukan oleh Karista (2005) memperlihatkan bahwa perbedaan gender juga berhubungan dengan perbedaan strategi regulasi emosi yang digunakan. 
Sumber data pada penelitian ini yaitu sumber data primer pada penelitian yang berupa teks tertulis atas respon fungsi emosional terhadap tokoh antagonis fiksi yang dilakukan pada kelas semester 5 program studi sastra Inggris Unpam, dengan jumlah responden 25 dan jumlah respon tertulis adalah 25. Menurut Sutopo (2002: 49) menyatakan bahwa sumber data merupakan bagian yang sangat penting bagi peneliti karena ketepatan memilih dan menentukan ketepatan dan kekayaan data atau informasi yang diperoleh.

\section{Metode dan Teknik Pengumpulan Data}

Dalam penelitian ini, peneliti menggunakan metode deskriptif kualitatif. Sugiyono, (2003:14) menyatakan bahwa, penelitian kualitatif adalah data kualitatif yang berbentuk kata, skema, dan gambar. Sedangkan Sutopo (2002: 35) menyatakan bahwa dalam mencari pemahaman, penelitian kualitatif cenderung tidak memotong halaman cerita dan data lainnya dengan simbol-simbol angka. Peneliti berusaha menganalisis data dengan semua kekayaan wataknya yang penuh nuansa, sedekat mungkin dengan bentuk aslinya seperti pada waktu dicatat. Menurut Bogdan dan Taylor (1975) dalam buku Moleong (2004:3) mengemukakan metode kualitatif sebagai prosedur penelitian yang menghasilkan data deskriptif berupa kata-kata atau lisan dari orang-orang dan perilaku yang dapat diamati. Berdasarkan pendapat di atas dapat dikemukakan bahwa metode deskriptif kualitatif adalah metode penelitian yang menghasilkan data deskriptif yang berbentuk kata, skema, dan gambar. Serta tidak memotong halaman cerita dan data lainnya dengan simbol-simbol angka.

\section{E. Tahap Pengolahan Data}

Mile dan Huberman seperti yang dikutip oleh Salim (2006: 20-24), menyebutkan ada tiga langkah pengolahan data kualitatif, yakni reduksi data (data reduction), penyajian data (data display), dan penarikan kesimpulan (conclusion drawing and verification). Dalam pelaksanaannya reduksi data, penyajian data, dan penarikan kesimpulan/verifikasi, merupakan sebuah langkah yang sangat luwes, dalam arti tidak terikat oleh batasan kronologis. 


\section{F. Teknik Analisis Data}

Teknik analisis data yang digunakan adalah analisis isi (content analysis). Dalam menganalisis isi respon tertulis yang berupa teks, maka yang harus dilakukan dalam menganalisis isi tersebut dengan membaca keseluruhan teks secara sistematis dan lengkap. Luxemburg, dkk (dalam Suwardi Endraswara, 2008: 74) menyatakan bahwa "Interpretasi adalah proses membaca dan menjelaskan teks yang lebih sistematis dan lengkap.

Pengumpulan data ini dilaksanakan selama 3 bulan. Pengumpulan data dimulai pada bulan Oktober sampai dengan bulan Desember 2016. Berikut adalah keterangan jadwal kegiatan penelitian dalam bentuk tabel:

\begin{tabular}{llccc} 
Nomor & \multicolumn{1}{c}{ Kegiatan } & \multicolumn{3}{c}{ Bulan Ke } \\
& & $\mathbf{1}$ & $\mathbf{2}$ & $\mathbf{3}$ \\
$\mathbf{1}$ & Persiapan \& Pengumpulan data & $\mathrm{X}$ & & \\
$\mathbf{2}$ & Pengolahan Data & & $\mathrm{X}$ & \\
$\mathbf{3}$ & Penyusunan data laporan & & & $\mathrm{X}$ \\
\hline
\end{tabular}

\section{G. Pembahasan Hasil}

Berikut adalah dua puluh lima responden dari mahasiswa semester lima program studi sastra Inggris yang telah menuliskan secara naratif terkait respon fungsi emotional mereka terhadap tokoh antagonis fiksi. Penelitian ini tentu saja mengacu pada fungsi emosional mereka berdasarkan perbedaan gendernya setelah membaca sebuah karya prosa fiksi berupa cerita pendek berjudul the Story of an Hour yang ditulis oleh Kate Chopin. Dari hasil analisis yang telah dilakukan terhadap 25 responden yang merupakan mahasiswa semester lima program studi sastra Inggris Universitas Pamulang dalam hal respon fungsi emosional terhadap tokoh antagonis fiksi maka berikut adalah pembahasan yang disampaikan secara deskripsi tabel. 


\begin{tabular}{|l|c|}
\hline \multicolumn{1}{|c|}{ Jenis Kelamin Responden } & Jumlah \\
\hline Responden Laki-Laki & 8 \\
\hline Responden Perempuan & 17 \\
\hline Jumlah & $\mathbf{2 5}$ \\
\hline
\end{tabular}

Jumlah responden laki-laki yang merespon secara netral atas fungsi emosional terhadap tokoh antagonis adalah 3, yaitu responden nomor 3, 5, dan 25. Mereka menunjukan respon emosi yang netral dan tidak menunjukan keberpihakan gender. Dalam pengertian bahwa paparan mereka akan tokoh antagonis tidak berkecenderungan memihak kesamaan jenis kelamin dan tidak menyertakan respon emosi dalam responnya. Sementara, 5 responden laki-laki dengan nomor $2,6,22,23$, dan 24 memberikan respon fungsi emosional yang negatif. Dalam hal ini mereka melakukan keberpihakkan gender secara respon emosional dengan menyampaikan tokoh antagonis adalah Mrs. Mallard yang berbeda jenis kelamin dengan para responden. Dalam menunjukan respon emosi, mereka memaparkan tokoh antagonis dalam diksi emosi negatif.

Pada responden perempuan yang berjumlah 17, empat responden menyampaikan respon fungsi emosional netral terhadap tokoh antagonis. Yaitu responden nomor 9, 11, 12, dan 14. Pada paparan respon netralnya, keempat responden menilai tokoh antagonis adalah Mrs. Mallard yang secara norma-norma sosial dianggap melakukan sikap dan perilaku yang tidak relevanterhadap norma yang dianut secara umum. Pada tigabelas responden perempuan lainnya, respon fungsi emosional mereka terhadap tokoh antagonis menunjukan keberpihakkan gender dengan paparan jenis emosi negatif terhadap tokoh antagonis yaitu Mr. Mallard. Dalam garis besar paparan ketiga belas responden tersebut, Mr. Mallard adalah jenis pria atau suami yang membuat hidup Mrs. Mallard penuh dengan kesedihan, depresi dan tidak menikmati perannya sebagai seorang istri. Diksi yang mereka sampaikan menunjukan pola-pola penyampaian fungsi emosi negatif dan memenuhi unsur perbedaan gender. Keseluruhan rekam dari hasil penelitian tentang perbedaan gender pada respon fungsi emosional terhadap tokoh antagonis fiksi yang dilakukan pada mahsiswa program studi sastra Inggris tersaji dalam tabel berikut. 


\begin{tabular}{|c|c|c|c|c|}
\hline \multirow{2}{*}{$\begin{array}{c}\text { Nomor } \\
\text { Responden }\end{array}$} & \multicolumn{2}{|c|}{ Pilihan Tokoh Antagonis } & \multirow{2}{*}{ Jenis Kelamin } & \multirow{2}{*}{$\begin{array}{c}\text { Respon Emosi } \\
\text { terhadap tokoh } \\
\text { antagonis }\end{array}$} \\
\hline & $\begin{array}{c}\text { Mr. Mallard } \\
\text { (laki-laki) }\end{array}$ & $\begin{array}{l}\text { Mrs. Mallard } \\
\text { (perempuan) }\end{array}$ & & \\
\hline 1 & $\sqrt{ }$ & & Perempuan & Pro Gender \\
\hline 2 & & $\sqrt{ }$ & Laki-laki & Pro Gender \\
\hline 3 & $\sqrt{ }$ & & Laki-laki & Netral \\
\hline 4 & $\sqrt{ }$ & & Perempuan & Pro Gender \\
\hline 5 & $\sqrt{ }$ & & Laki-laki & Netral \\
\hline 6 & & $\sqrt{ }$ & Laki-laki & Pro Gender \\
\hline 7 & $\sqrt{ }$ & & Perempuan & Pro Gender \\
\hline 8 & $\sqrt{ }$ & & Perempuan & Pro Gender \\
\hline 9 & & $\sqrt{ }$ & Perempuan & Netral \\
\hline 10 & $\sqrt{ }$ & & Perempuan & Pro Gender \\
\hline 11 & & $\sqrt{ }$ & Perempuan & Netral \\
\hline 12 & & $\sqrt{ }$ & Perempuan & Netral \\
\hline 13 & $\sqrt{ }$ & & Perempuan & Pro Gender \\
\hline 14 & & $\sqrt{ }$ & Perempuan & Netral \\
\hline 15 & $\sqrt{ }$ & & Perempuan & Pro Gender \\
\hline 16 & $\sqrt{ }$ & & Perempuan & Pro Gender \\
\hline 17 & $\sqrt{ }$ & & Perempuan & Pro Gender \\
\hline 18 & $\sqrt{ }$ & & Perempuan & Pro Gender \\
\hline 19 & $\sqrt{ }$ & & Perempuan & Pro Gender \\
\hline 20 & $\sqrt{ }$ & & Perempuan & Pro Gender \\
\hline 21 & $\sqrt{ }$ & & Perempuan & Pro Gender \\
\hline 22 & & $\sqrt{ }$ & Laki-laki & Pro Gender \\
\hline 23 & & $\sqrt{ }$ & Laki-laki & Pro Gender \\
\hline 24 & & $\sqrt{ }$ & Laki-laki & Pro Gender \\
\hline 25 & $\sqrt{ }$ & & Laki-laki & Netral \\
\hline
\end{tabular}




\section{KESIMPULAN}

Dari hasil proses perkuliahan prosa fiksi dengan membaca karya-karya penulis dalam bentuk cerita pendek ataupun novel, didapati respon-respon yang berbeda pada setiap mahasiswa berdasarkan kategori jenis kelamin. Respon tersebut merujuk pada paparan bagaimana mereka menentukan tokoh antagonis. Perbedaan gender pada respon fungsi emosional terhadap tokoh antagonis fiksi dinarasikan dalam bentuk emosi negatif, netral atau positif. Emosi negatif adalah apa yang dipaparkan adalah hasil dari memandang dan menginterpretasikan sebuah peristiwa dalam persepsi atau penilaian negatif, tidak menyenangkan, menyengsarakan, menjengkelkan, mengecewakan. Sementara paparan emosi positif seperti sebuah kewajaran, hal yang indah, sesuatu yang mengharukan, atau membahagiakan. Dari data narasi yang diperoleh dari para responden disimpulkan bahwa perbedaan jenis kelamin memberikan respon emosi yang berbeda dan menjadikan respon emosi yang berbeda tersebut sebagai hal perbedaan gender.

\section{DAFTAR PUSTAKA}

Universitas Press

2005, Teori Pengkajian Prosa dan Fiksi, Yogyakarta, Gajahmada

Ahimsa-Putra, Heddy Shri, 2006, Strukturalisme Levi-Strauss Mitos,

Aminuddin. 1987, Pengantar Apresiasi Karya Sastra, Bandung, Sinar Baru Algesindo.

Azwar, S, 1988, Sikap Manusia Teori dan Pengukurannya, P u s t a k a, Yogyakarta.

Berry, John W., Ype H, Poortinga, H. Segall, Marshall \& Dasen, Pierre R., 1999, Psikologi

Lintas Budaya, Riset dan Aplikasi, Jakarta, PT Gramedia Pustaka Utama

Cannon, W.B. (1927), "The James-Lange theory of emotions: A critical examination and an alternative theory", The American Journal of Psychology.

Chaplin, J. P. (1999), Kamus Lengkap Psikologi, penerjemah: Kartini Kartono. Jakarta, PT Raja Grafindo Persada

Crow L\& A. Crow. (1988). Psikologi Pendidikan, Surabaya, Bina Ilmu, dan Karya Sastra, Cetakan pertama, Yogyakarta, Kepel Press.

Daniel Goleman, (1995), Emotional Intelligence, New York, Bantam Books.

Echol, John M., 2003 dan Hasan Shadily, Kamus Inggris Indonesia, Jakarta, PT Gramedia Pustaka Utama.

Ekman, Paul, (2003) Membaca Emosi Orang,Yogjakarta, Think. 
Fakih, Mansour, 2008, Analisis Gender dan Transformasi Sosial, Yogyakarta: INSISTPress.

Halpern, D. F. (2004), "A cognitive-process taxonomy for sex differences in cognitive abilities", Current Directions in Psychological Science, 13 (4), 135-139.

Herman J, Waluyo, 2002, Pengkajian Sastra Rekaan, Salatiga, Widya Sari Press.

Illich, Ivan. 2005, Matinya Gender, Yogyakarta, Pustaka Pelajar. Jakarta, Raja Grafindo

John T. Cacioppo and Richard E. Petty (1984),"The Elaboration Likelihood Model of Persuasion", in NA - Advances in Consumer Research Volume 11, eds.

Keltner, D., Kring, AM., Bonanno, A. 1999. Fleeting signs of the course of life: Facial expression and personal adjustment. Current Directions Jil PsycholoJicaIScjen 8-1, $18-22$

Lexy J. Moleong, 2004, Metodologi Penelitian Kualitatif, Bandung: PT. Remaja Rosdakarya Media.

Lips, Hilary M., 1993, Sex \& Gender an Introduction, California, London, Toronto: Mayfield Publising Company.

Melani Budianta, dkk. 2008, Membaca Sastra (Pengantar Memahami Sastra untuk Perguruan Tinggi), Yogyakarta, Indonesia Tera.

Moleong, Lexy J, 2002, Metodologi penelitian Kualitatif. Bandung, Remaja Rosdakarya.

Nugraheni Eko Wardani, 2009, Makna Totalitas Dalam Karya Sastra, Surakarta, LPP UNS dan UNS Press.

Nurgiyatoro, Burhan, 2007, Teori Pengkajian Fiksi, Yogyakarta: Gajahmada UniversityPress.

Ratna, Nyoman Kutha. 2004, Teori, Metode dan Teknik Penelitian Sastra, Yogyakarta, Pustaka Pelajar.

Salim dan Syahrum, 2006, Metodologi Penelitian Kualitatif, Bandung:Citapustaka.

Semi, Atar, 1990, Metode Penelitian Sastra, Padang: Angkasa.

Soekanto, Soerjono, (1993), Sosiologi Suatu Pengantar, Jakarta, Raja Grafindo Persada.

Sudjiman, Panuti, 1991. Memahami Cerita Rekaan, Jakarta, Pustaka Jaya

Sugiyono. 2003, Metode Penelitian Bisnis. Bandung, Pusat Bahasa Depdiknas.

Sutopo. 2002, Metodologi Penelitian Kualitatif, Dasar Teori dan Terapannya dalam Penelitian, Surakarta, Sebelas Maret University Press.

Suwardi, Endraswara, 2008, Metode Penelitian Psikologi Sastra Teori, Langkah dan Penerapannya, Yogyakarta, MedPress.

\section{Data online}

Pembelajaran Gender (online) dikases 27 November 2016,

https://id.wikipedia.org/wiki/Pembelajaran_gender 